\title{
Retail Concentration: The Shopping Streets
}

\author{
Pierluigi Passaro \\ Lecturer of Marketing \\ Sergio Salomone \\ Teaching Assistant of Marketing \\ Luca Petruzzellis \\ Associate Professor of Marketing
}

doi: 10.19044/esj.2016.v12n16p122 URL:http://dx.doi.org/10.19044/esj.2016.v12n16p122

\begin{abstract}
Changes in consumer lifestyle strongly affect the retail demand, forcing the distribution system to reorganize and reposition its offer. Shopping proves to be a differentiating "activity", given that buying behavior is even more characterized by psychological and emotional factors, thus the purchased goods and the stores patronized become lifestyle symbols. However, a dualism between the retail dynamic needs and the existing spatial conditions exists. The former, especially in the case of fashion and shopping goods, requires a strategic position as close to customers as possible, namely huge spaces, attractive locations where the consumer need for experience and entertainment is met. The latter could be modified gradually and partially, determining a location hierarchy that results from wider changes in politics, economy and society. Consequently, all cities are experiencing a renewal process in their shopping "spaces"; retailers are competing for a front space on the streets in order to gain more visibility through huge and sparkling stores - and "label" their products through values, symbols, and emotional/entertaining experience. This paper investigates the spatial/territorial dimension of consumption, analyzing the concentration phenomenon among shops from the same sector or complementary ones. By exploiting agglomeration economies shops can be positioned in the consumers' mind, firstly, with the street's collective image and then with the shop's specific image. The purpose of this study is to determine the extent to which shopping streets (also referred to as the high street, downtown or city centre) provide retail concentration.
\end{abstract}

Keywords: Retail, concentration, customers, lifestyle 


\section{Introduction}

In the city's history, the traditionally commercial areas have always played a fundamental role in the construction of urban communities for their innate vocation of places of socialization, in terms of economy, culture and social life (Carr et al., 1992, Trillo et al., 2012).

These places constituted, in the past, veritable "natural malls", as result of slow sedimentation of productive and commercial activities that could be construed as an integrated system. The retail, though in different contexts and periods, has always played a key role in creating and maintaining the identity of a district (Jacobs, 1961). Commercial districts, in fact, play a central role in the life of the city; when they are "healthy" and vibrant, attracts residents and tourists and encourage investors; on the contrary, when they are degraded and “dormant” attract criminal activity and distract investors.

The importance of commerce in the construction of social networks is closely related to the role of public spaces (Esposito De Vita, 2013b); in particular, in town centers and in consolidated city, market squares and shopping streets have always been the fulcrum of urban and social structure (Atkinsons, 2003. Carmona et al., 2010; Zukin, 2010).

However, historic centers of many Italian and European cities, in general, are going through a period of crisis due to several causes as demographic, social, cultural and economic, such as depopulation, the loss of "cultural identità", the decreased ability to recall the small town retail (Paparelli and Del Duca, 2010), compared to the policies more "aggressive” of modern distribution (hypermarkets, shopping centers, factory outlet village) - concentrated in suburban areas that offer cheaper real estate solutions and attracts international competitors (Zukin, 1998; LoukaitouSideris, 2000; Halebsky, 2004; Lowe, 2005; Sansone, 2007) - and of imposing of phenomena such as e-commerce.

In this context, it is seen as retail agglomerations are an omnipresent feature of the urban environment in both developed and developing nations and, as such, are an important element of the urban "place product” (Whyatt, 2004; Short \& Kim, 1998). As "landscapers of cities" retailers have an influence on how attractive place users perceive an urban place to be (Warnaby \& Davies, 1997). Not only are store clusters a reaction to the increasing competition that exists amongst urban places, such as districts, towns and cities (Teller \& Reutterer, 2008), but they function as attractors for multiple, yet heterogeneous, place user groups - for example, prospective and existing residents, tourists, visitors, consumers and employees (Shaw \& Williams, 1992).

To market an urban environment - which retail agglomerations are an integral part of - it is crucial to understand a place's characteristics relative 
to its competitors and to identify the different place user groups that inhabit it (Hospers, 2006).

Concurrently, place marketing strategies and activities, as part of the "place formation process" (Aiesha, 2006), must be directed and focussed towards specific place user groups in order to better ensure commercial success (Madsen, 1992). Thus, in turn, place marketers need to know why their place is seen to be attractive compared to others from a place user's point of view (Skinner, 2008). Insch and Florek (2008) note that the nature of "place satisfaction" needed to be better understood. This is particularly pertinent for those place users who patronise a specific urban environment, i.e. actual shoppers - those consumers who express some degree of loyalty and/or preference towards a particular urban environment - as well as the retail agglomerations located there.

To date, however, the place marketing literature has tended to favour the “place product” supplier or managers' view (Gower, 2008).

Indeed, only a few authors have dealt with retail agglomerations within urban places from a consumer's point of view but with this being undertaken through the focus of retail managers (Teller \& Elms, 2010). Nevertheless, competition between and attractiveness of urban retail areas on an aggregated level has been considered in older publications often informed by spatial interaction theory, as well as by more recent articles where multiplicative competitive interaction models have been used (for literature review see Teller \& Reutterer, 2008).

Like created retail agglomerations, store clusters within urban places generate agglomeration effects (Teller et al., 2008). These synergistic effects are due to outlets being nearby to one another and this can lead to benefits for both retailers and consumers (Schnedlitz \& Teller, 2008; Oppewal \& Holyoake, 2004). Retailers located in urban retail agglomerations can use infrastructural services that they do not have themselves (Teller \& Elms, 2010). In general an agglomeration's customer streams are not generated by any store acting alone; rather they are the consequence of this process of clustering (Teller, 2008).

From a consumer's perspective, urban retail agglomeration can be used to conduct multi-purpose trips (e.g., Reimers \& Clulow, 2004; 2009; Baker, 1996). These trips not only include satisfying bundles of wants and needs at one place, but also spending their leisure time (eating, drinking and entertainment), meeting or visiting other people who live there or using other services offered by banks, non retail businesses or even the council administration. All the mentioned retail related attributes of urban retail agglomerations underpin the attractiveness of such places for consumers.

To address these needs and contribute with concrete initiatives for redevelopment and revitalization of cities, old towns and areas once 
prestigious for business, meeting, socializing, have sprung the Natural Shopping Centres, modern forms of association and cooperation of all traders of the city center (trade, public services, handicrafts, tourism, services, professional activities), aimed at achieving common policies marketing and communication (Paparelli \& Del Duca, 2010). Currently there is a gap in the procedures for spatial transformations, which aim to promote the conservation and development of traditional crafts as a motor for urban regeneration processes (Beatley \& Manning, 1997; Esposito De Vita et al., 2013b).

No coincidence that there is a close link between commerce and tourism which is important as a result of the recognition of the cultural heritage of a place as interweaving of tangible and intangible elements, which the tourists themselves are particularly sensitive. In this perspective, in fact, retail is no longer a simple service to tourists but is an active builder of local identity, is part of the cultural heritage of the place. The commerce - in its places, traditions, and product categories - helps to form the soul of the city and neighborhoods.

In particular, according Zukin (2012), the contribution of commerce to the formation of "local cultural ecosystem" covers three aspects: 1) the mobilization of powerful aesthetic themes related to the way stores are shown to the eye (exhibitions, architecture , signs, etc.); 2) the production and conservation of collective memory, mainly due to the persistence of local businesses, to counter the advance of the big chain stores that tend to approve the landscapes of historic centers; 3) the construction of dense social practices based on the interaction between retailers and customers, important to spread local "know how".

In the present case, this paper examines the case of Murat district of Bari, located in the heart of the city, which is part of the IX constituency (Murat - St. Nicholas “Old Town”), which covers approximately 1.05 square kilometers, with a resident population of about 17,000 people. The IX district has one of the highest population densities in the city, with almost 17,000 people per square kilometer, compared to the average city of about 3,000.

The Murat district hosted the first experiments of pedestrianization, outside the historic city. In particular via Sparano was pedestrianized in 2007, becoming one of the main shopping streets of the city. Recently, at the end of 2011, also via Argiro, the parallel of Via Sparano was partly pedestrianized with the same aims.

The Murat neighborhood is home to a mix of functions (residences, business, universities, other public and private services) and provides a vital transit hub and passing through the urban mobility. 


\section{Background}

Retail and brands represent the key success factors to compete in the international arena. Stores become the place where the marketing strategies of a firm come to life; in them firm communicates, fosters the loyal relationship with their customers and constantly monitors market tastes and needs. The store is a determining factor in the brand image and brand identity building processes, since it is the first place to contact the consumer. Store interactivity has to be boosted in order to collect more information on consumer needs and shopping behavior.

To date retail caters to a wider specialization, serving specific target markets with different lifestyles and transmitting images, symbols and emotions. On the other hand, it presents deep fragmentation, limited efficiency in the distribution network and the high presence of small independent shops. This structure derives from the sector's need for differentiation, since the point of sale increases the product added value (Ravazzoni and Panciroli 2002). Store is no longer only a logistic-operative thrust but also a more complete marketing one, especially from a relational point of view.

Location and consequently the point of sale have two dimensions: the firm one and the consumer one. They should be combined in the search for a store loyalty that matches the brand one. So far stores are physically structured in relation to the spatial position and the products sold, in order to attract consumers and create an ambience (Kotler 1973) in which to live an experience. In order to enter the consumer evocative set, the store has to make such an impression as to be positively remembered in the decisionmaking process while choosing products and brands (Stoltman et al. 1990). Empirical studies (e.g., Paulins and Geistfeld 2003) found location, service, assortment depth, price strategies, quality, and store ambience to be discriminatory factors in the relation between retail and customers. In particular, the physical features such as layout, colors, music and crowding, result as strongly affecting shopping behavior and store choice (e.g., Chebat et al. 2001; Babin et al. 2004). For example, overcrowded stores can inhibit the shopping behaviour and cause various reactions, that range from reducing the store visit frequency to postponing the scheduled purchases or giving up the shopping expedition entirely (Donovan et al. 1994).

Moreover, store positioning proves to have a strong correlation not only with product features, such as quantity, quality and services, but also with marketing ones, namely price strategies, store format, time factors, benefit sought, consumer's perception and shopping behavior. All these elements are summarized in the store image, that is strictly correlated to the quality and reputation of the brands sold in it. The store ambience features strongly affect the consumption volume and nature. As Lovemark (1972) 
maintained, "sunshine stimulates shopping”, in order to define purchasing behavior especially in the northern regions.

This phenomenon is obvious especially for fashion products, in which brand notoriety is combined with particular locations. Firms try to create a glamour context around brands in order to realize an unforgettable experience not only in buying and consuming the product but also in the time spent choosing it within a stylish environment.

In this scenario retail is spatially redefining social spaces and the relations within the city, through the traffic flows it causes. The complex functions of selling require specific locations; from city centers, suburbs, high streets, stations, airports, and so on; while globalization and the consequent enlargement of space and time relations, necessitate easy access, no separation of the street by huge windows, and free service. Therefore a new relation between consumers and retailers is created, based exclusively on psychological and emotional factors; image and the consumers perception of it play an important role.

Consumption, and its display - shopping-, are shaping city's identities and functions in relation to consumers' needs. The so-called "percorsi degli elefanti" (Amendola 1998) create a network that assigns new vitality and dynamism to goods and people flows.

Therefore, location strategies tend towards concentration in order to follow the evolution of consumer needs: for convenience goods concentration results in purchases in a single store; while for shopping goods concentration is the solution to the issue of minimizing search costs. On one hand, consumers look for detailed information on product prices, quality and variety, and on the other for entertainment and fun while shopping. To match consumer needs firms are forced to locate their stores near their competitors in the so-called shopping districts/streets.

Such a concentration derives from belonging to complementary sectors and from the presence of magnet stores that modify shopper traffic and mobility, given also the customer exchange among nearby similar commercial types (Mc Keever and Griffin 1977). So agglomeration is demand pull; it is possible to offer a complete set of products, that can be bought in the same shopping expedition, granting savings of time and space. At present distance is no longer the main discriminating factor, it becomes a marketing factor rather than a geographical one. Nowadays accessibility results as the key "shopping" criterion. To be located in the city centre does not assure success in itself; it is the "accessibility image" that counts. So far the trade-off between distance and dimension is influenced by consumers' perception of the specific store image and of the store network one (Campo et al. 2000). 
Urban areas seem to be the best locations for shopping agglomerations by nature. They offer visibility and direct contact as near as possible to consumers, both potential and actual. On the other hand, firms are searching for larger spaces to locate their activity and create an ambience in which consumers can experience more fun and entertainment while shopping. Unfortunately, these requirements match higher location costs and are suitable only for certain products, such as fashion ones. However, spatially they stimulate a repositioning process of city centers and their streets. Throughout all the Italian cities, Bari has been chosen for its long established commercial tradition. As it can be observed in most of Europe, the city is repositioning its image, having lost its regional and provincial commercial leadership. Within its structure, the city centre is suffering strong competition from the suburbs where shopping malls are able to attract many consumers from different areas due to price strategies, the worsening of urban accessibility and the lack of "entrepreneurship”/collaboration among central retailers (Petruzzellis and Falcone 2005).

\section{Research methods}

The phenomenon has been studied in Bari, an Italian city with a strong commercial tradition. The fashion sector has been chosen for its symbolic function with a psychological- the expression of personality - and a sociological - the identification and differentiation of the human being dimensions (Baudrillad 1972).

The paper will try to understand which factors affect shop attractiveness and especially to which extent the territorial variable, i.e. agglomeration, influences shopping expeditions. Street perception from the place and retail marketing point of view has been analyzed. Three streets in Bari, namely via Argiro, Corso Cavour and via Sparano, have been considered since they are the most representative from the shopping point of view, both for store number and type, and for their tradition and position. They are perceived as a shopping district within the commercial heart of the city but each with a specific feature: via Argiro is a female oriented street, via Sparano is the city's showcase or "promenade", corso Cavour is the most accessible both physically and for the products sold. Like the whole city, the three streets experienced a repositioning process that follows consumer evolution, especially for the fashion sector. In fact, via Argiro was formerly a wholesale street, but has now become an exclusive street to find specialty goods; corso Cavour, due to its strategic position and its easy physical and commercial access, is the middle class street. Lastly via Sparano, one of the oldest city's streets, is the commercial heart of Bari, in which its identity is displayed. Most of the single brand stores of the city are located there.

Data have been collected in one day by interviewing a random 
sample of 500 people, who were shopping in the three streets. 334 completed the questionnaire. The sample is mostly composed of women, due to sociological and marketing factors, and the average age is approximately forty. As regards gender, sociology explains women's natural attitude through shopping, while marketing explains the huge presence of clothing and shoes stores. Instead the young age is due not only to the location of glamour stores in the streets considered, but also to the location of exclusive cafes and meeting points.

\section{Results and discussion}

Firstly, the relation between demographic factors, such as gender, age and distance, and customer loyalty, that measures shopping behavior, has been investigated through the chi square statistical analysis (Johnson 1997). The demographic variables do not influence customer loyalty and consequently shopping behavior, but influence the image and characterization of the streets, considered as a structured set of stores. Only via Sparano shows a dependent relation between customer loyalty and age and distance (see Table 1). This seems to derive from factors related to store typology, specifically fashion, and from territorial factors combined with marketing ones, such as the street's image, especially for via Sparano.

Table 1. Chi square for the 3 streets

\begin{tabular}{|c|c|c|c|c|c|c|}
\hline Variables & \multicolumn{2}{|c|}{ Via Argiro } & \multicolumn{2}{c|}{ Corso Cavour } & \multicolumn{2}{c|}{ Via Sparano } \\
\hline & Chi square & $\mathrm{p}$ & Chi square & $\mathrm{p}$ & Chi square & $\mathrm{p}$ \\
\hline Age-Customer loyalty & 1.49 & .335 & 6.57 & .392 & 62.57 & .001 \\
\hline Gender-Customer loyalty & 5.45 & .893 & 1.52 & .313 & 2.56 & .372 \\
\hline $\begin{array}{c}\text { Distance-Customer } \\
\text { loyalty }\end{array}$ & 61.18 & .001 & 3.56 & .834 & 56.24 & .016 \\
\hline
\end{tabular}

In order to analyze why the street is patronized and its influence on shopping behavior, the usage of the streets has been investigated. Via Argiro and corso Cavour result to be used only for shopping while via Sparano is used also for walking or meeting people, and often, while crossing it, the buying decision is taken.

In particular, via Argiro is used only for feminine glamour shopping, even though it is physically one of the first streets of the city. Also the time spent on shopping confirms the findings: 61\% spends 1-3 hours, $21 \%$ less than 1 hour, and 18\% more than 3 hours. Moreover, the other facilities such as cafes and meeting points, can attract potential users/shoppers, rendering the street enchanting. Corso Cavour has a strong commercial vocation, so consumers frequent it only for shopping without being loyal to specific stores. They spend much time (more than 2 hours for 39\%) shopping in the street due to the opportunity it provides to compare products and to the 
“distance” factor [5]. On the contrary via Sparano is also used for walking, especially because it is a pedestrian precinct, that has labeled it as the "living room" of the city, although the street is losing its brightness due to the worsening of the accessibility conditions.

In order to investigate the position of the three streets in the consumers' minds, the purchase motivations have been analyzed through the correspondence analysis (Grewal et al. 1999).

Figure 1. Purchase motivations

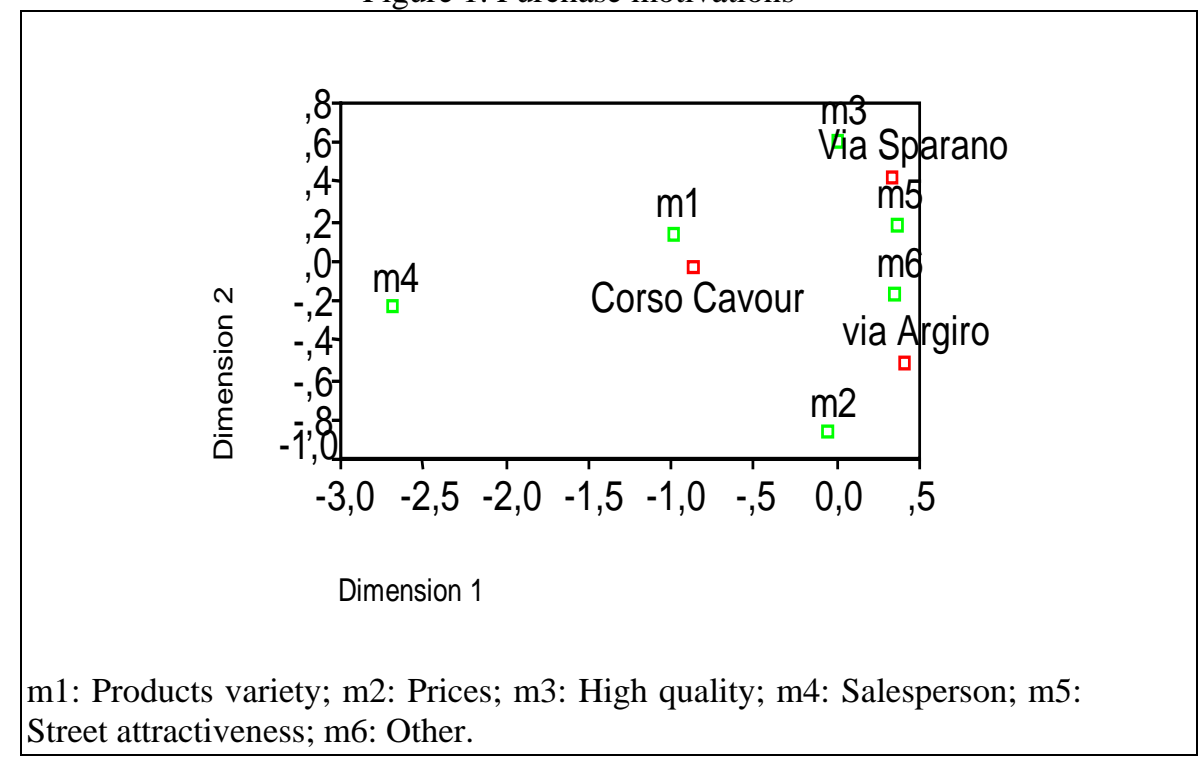

As in figure 1, people choose to shop in the three streets for different reasons; in particular, corso Cavour is chosen for its wide range of products, which represents a weakness rather than a strength because it contributes to a confused image. Via Argiro is chosen for its prices that, even though considered high, do not prevent consumers frequenting it. Instead they contribute to fostering the perception as a stylish shopping street and creating a sort of loyalty discriminated by premium price. Customers are willing to pay high prices for fashionable and trendy products. Finally, via Sparano attracts consumers for the high product quality and its good reputation. It is the street with the highest percentage of loyal customers (60\%) especially for the prestigious fashion brands sold.

As a consequence, the positioning map (see fig. 2) defines three areas in relation to shoppers' perception. Via Sparano and via Argiro are perceived as well defined, stylish streets, whose fashionable and trendy products and stores are differentiating elements that contribute to legitimizing the brand identities and their premium prices that derive also from the location. Especially in the case of via Sparano, the street positioning derives from its tradition, but has repositioned itself in order to follow consumer and fashion 
evolution, by changing its front and store type. On the other hand, corso Cavour has a less clearly defined positioning, due to its confused perception. That is why the high variability and the wide variety of store types that are not often coordinated.

Figure 2. Positioning map

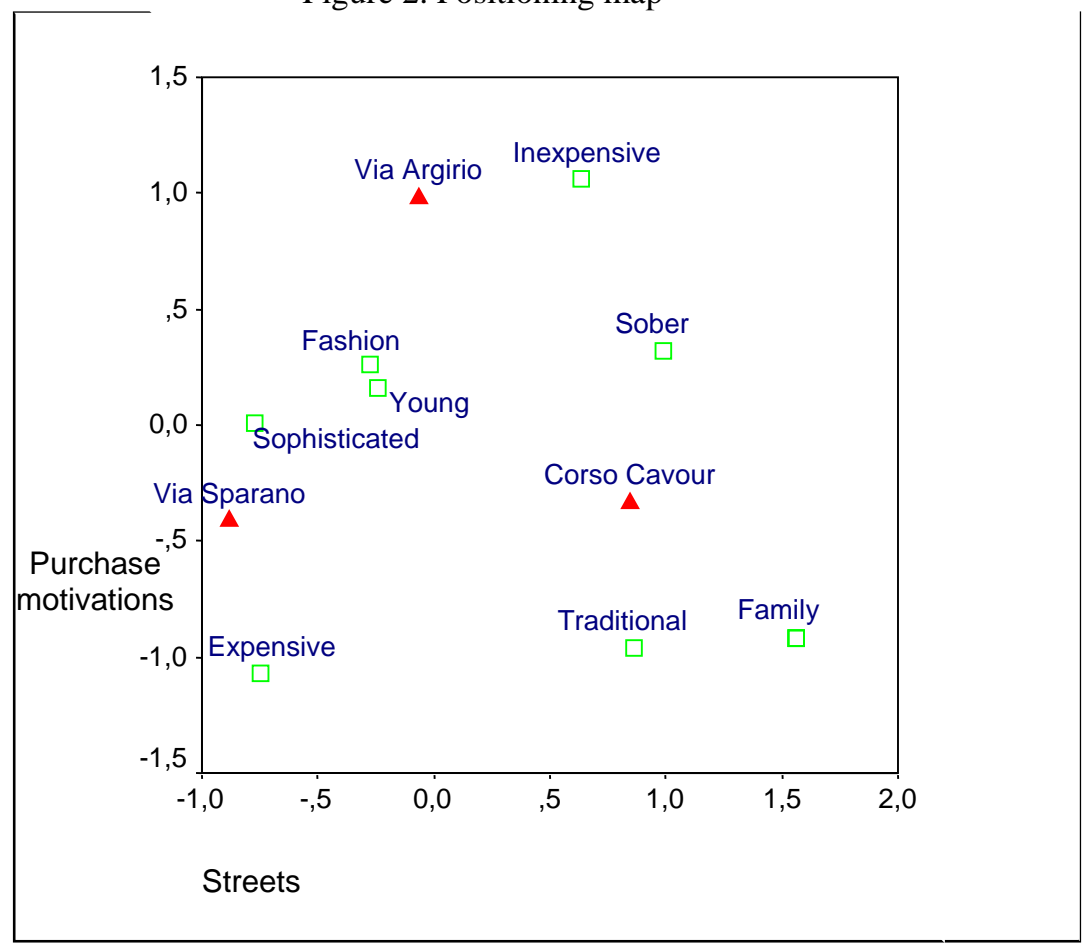

The study highlights how retail concentration is based on market multi-segmentation. It results as a new strategic opportunity to avoid the saturation of customers' positioning perceptual map, filled by similar values and messages (Featherstone 1994). The store proves to be the place where a firm's identity is displayed and brand identity is built, and, together with the territory, creates a relational contest to provide pleasant experiences.

The shopping streets and city centre are seen as brands with "symbolic value and personality" (Brown 1992) which can be developed and maintained (Warnaby and Davies 1997). Shopping streets can be seen as a "bundle of benefits", both tangible and intangible, which creates relations that cause crossing flows of customer in relation to the dimension and the attractiveness of the various retail activities, and that foster vitality for the city they serve.

In conclusion, retail concentration is a strategic element both for firms and for cities in order to be part of the competition. Therefore, it is a marketing thrust that boosts and helps create brand identity, increasing the relational tools to impact consumer perception. 


\section{Conclusion}

From the measures taken, this study provides insight into the degree of retail concentration offered by a sample of three shopping streets.

The results have produced three important insights.

First of all the demographic variables do not influence customer loyalty and consequently shopping behaviour, but influence the image and characterization of the Streets, Considered as a structured set of stores.

In the second place the sample of roads taken into consideration is appreciated for the diversity of their characteristics. From those used only for shopping feminine charm, the one with a strong commercial vocation to that, finally, it offers several alternatives of use as pedestrian.

The emergence of the Internet and a more demanding consumer has created the need for traditional malls to provide a more convenient shopping environment. A business center provides convenience when minimizes the cost, space and time effort shopping. Existing strategies for convenience space include limiting the size of a shopping center by controlling the entry of non-commercial enterprises, creating a compact physical design, and creating regional clusters of compatible shops. The authors' propose an alternative method; the degree of concentration of retail sale.

\section{References:}

Aiesha, R. (2006). Place Marketing and the Planning Process. In Proceedings of the CIRM Conference - Destinations and Locations: Exploring the Multiple Identities of Place (pp. 1-2). Manchester: Manchester Metropolitan University.

Atkinson R. (2003), “ Addressing urban social exclusion through community involvement in urban regeneration” , in Imrie R. e Raco M. (eds), Urban Renaissance? New labour, community and urban policy . Policy Press, Bristol, UK, pp. 101-119.

Baker, R. G. V. (1996). Multi-purpose Shopping Behaviour at Planned Suburban Shopping Centres: A Space-Time Analysis. Environment and Planning A, 28, 611-630.

Beatley T., Manning K. (1997), The ecology of place: planning for environment, economy and community. Island Press, Washington, D.C.

Carmona M., Heath T., Oc T., Tiesdell S. (2010), Public places urban spaces: the dimensions of urban design . Routledge, London, UK.

Carr S., Francis M., Rivlin L. G., Stone A. M. (1992), “ Needs in public space” , in Carr S. (ed.), Public space . Cambridge University Press, Cambridge, MA.

Esposito De Vita G., Bevilacqua C., Trillo C. (2013a), “ Improving conviviality in public places: the case of Naples, Italy” . Journal of Civil Engineering and Architecture, vol. 7, pp. 1209-1219. 
Esposito De Vita G., Trillo C., Oppido S. (2013b), “ Rigenerazione degli spazi pubblici e centri commerciali naturali: il caso di Piazza Mercato e Borgo Orefici a Napoli”, Proceedings of XVI Conferenza Nazionale SIU, Urbanistica per una diversa crescita. Italia, Napoli, May 9-10, 2013.

Gower, R. (2008). People-Managed Places. Journal of Place Management and Development, 1, 315-321.

Halebsky S. (2004). “ Superstores and the politics of retail development” . City \& Community , vol. 3, n. 2, pp. 115- 134.

Hospers, G-J. (2006). Borders, Bridges and Branding: The Transformation of the Oresund Region into an Imagined Space. European Planning Studies, 14, 1015-1033.

Insch, A., \& Florek, M. (2008). A Great Place to Live, Work and Play: Conceptualising Place Satisfaction in the Case of a City's Residents. Journal of Place Management and Development, 1, 138-149.

Jacobs J. (1961), The death and life of great American cities . Random House Digital, New York, NY.

Loukaitou-Sideris A. (2000). “ Revisiting inner-city strips: A framework for community and economic development” . Economic Development Quarterly , vol. 14, n. 2, pp. 165-181.

Lowe M. (2005), “ The regional shopping centre in the inner city: a study of retail-led urban regeneration”. Urban Studies, vol. 42, n. 3, pp. 449-470.

Madsen, H. (1992). Place-Marketing in Liverpool: A Review. International Journal of Urban and Regional Research, 16, 633-640.

Oppewal, H., \& Holyoake, B. (2004). Bundling and Retail Agglomeration Effects on Shopping Behaviour. Journal of Retailing and Consumer Services, 11, 61-74.

Paparelli R., Del Duca M. (2010), Centri commerciali naturali. Strategia e strumenti di network marketing a servizio del commercio, del turismo e del terziario. Angeli, Milano.

Reimers, V., \& Clulow, V. (2004). Retail Concentration: A Comparison of Spatial Convenience in Shopping Strips and Shopping Centres. Journal of Retailing and Consumer Services, 11, 207-221.

Reimers, V., \& Clulow, V. (2009). Retail Centres: it s time to make them convenient. International Journal of Retail and Distribution Management, 37, 541-562.

Sansone M. (2007), “ Confronti metodologici, riflessioni critiche e proposte operative sul Marketing Urbano in ambito internazionale: focus sull' organizzazione e gestione dei Centri Commerciali Naturali in Italia” . Proceedings of VI Congresso Internazionale Italia - Francia Marketing Trends . Paris, France, January 26-27, 2007.

Schnedlitz, P., \& Teller, C. (2008). Das Einkaufszentrum als Agglomerationsklasse begriffliche Diskussion und empirische Evaluierung 
von Agglomerationseffekten [Shopping centers as a distinct agglomeration format - conceptual discussion and empirical evaluation of agglomeration effects]. In M. Gruber (Ed), Agglomerationseffekte und Bestandverhaeltnisse in Einkaufszentren [Agglomeration effects and leasing agreements in shopping centers] (pp. 1-52), Vienna: Manz.

Shaw, G., \& Williams, A. (1992). Tourism, Development and the Environment: The Eternal Triangle, in: C.P. Cooper, \& Lockwood, A. (Eds.), Progress in Tourism, Recreation and Hospitality Management, Vol. 4 (pp. 47-59), London: Belhaven Press.

Short, J. R., \& Kim, Y-H. (1998). Urban Crises/Urban Representations: Selling the City in Difficult Times. In T. Hall, \& Hubbard, P. (Eds.), The Entrepreneurial City: Geographies of Politics, Regimes and Representations (pp.55-75), Chichester: John Wiley.

Skinner, H. (2008). The Emergence and Development of Place Marketing's Confused Identity. Journal of Marketing Management, 24, 915-928.

Teller C., \& Elms, J. R. (2010). Managing the Attractiveness of Evolved and Created Retail Agglomeration Formats. Marketing Intelligence \& Planning, 28, 25-45.

Teller C., Kotzab, H., \& Grant, D. B. (2006). The Consumer Direct Services Revolution in Grocery Retailing: an exploratory investigation. Managing Service Quality, 16, 78-96.

Teller, C. (2008). Shopping Streets Versus Shopping Malls - Determinants of Agglomeration Format Attractiveness from the Consumers' Point of View. International Review of Retail, Distribution and Consumer Research, 18, 381-403.

Teller, C., \& Reutterer, T. (2008). The Evolving Concept of Retail Attractiveness: What Makes Retail Agglomerations Attractive when Customers Shop at Them?” Journal of Retailing and Consumer Services, 15, 127-143.

Teller, C., Reutterer, T., \& Schnedlitz, P. (2008). Hedonic and Utilitarian Shopper Types in Evolved and Created Retail Agglomerations. International Review of Retail, Distribution and Consumer Research, 18, 283-309.

Trillo C., Esposito De Vita G., Oppido S. (2012), “ How to cope with the commercial decline of traditional market areas? Possible approaches and tools from the Città Bassa of Naples" . Proceedings of Ambivalent Landscape. Sorting out the present by designing the future . Lisboa, Portugal, December 6-7, 2012.

Warnaby, G., \& Davies, B. J. (1997). Commentary: Cities as Service Factories? Using the Servuction System for Marketing Cities. International Journal of Retail and Distribution Management, 25, 204-210. 
Whyatt, G. (2004). Town Centre Management: How Theory Informs a Strategic Approach. International Journal of Retail and Distribution Management, 32, 346-353.

Zukin S. (1998), " Urban lifestyles: diversity and standardization in spaces of consumption”. Urban studies, vol. 35, n. 5-6, pp. 825- 839.

Zukin S. (2010). Naked city: The death and life of authentic urban places . Oxford University Press, Oxford, UK.

Zukin, S. (2012). "The Social Production of Urban Cultural Heritage: Identity and Ecosystem on an Amsterdam Shopping Street”, City, Culture and Society, 3(4): 281-291. 